\title{
A DESIGUALDADE SÓ AUMENTA PREJUÍZOS E DIMINUI AS OPORTUNIDADES
}

O artigo publicado pela Química Nova em fevereiro de 2010 "Produtividade em pesquisa do CNPq: análise do perfil dos pesquisadores da Química" - por pesquisadores do CNPq, ${ }^{1}$ traça um perfil da bolsa de produtividade em pesquisa, tendo como foco a área da Química. É um trabalho muito interessante que deveria ser lido por todos que se interessam pelos caminhos da ciência no país e, em particular, os da Química. O ineditismo deste trabalho, obviamente, não está só nos seus resultados, mas por ter sido produzido por pesquisadores de uma agência de fomento. Isso abre caminhos para outras análises mais profundas dos resultados alcançados pelo $\mathrm{CNPq}$ em termos de bolsas e editais de fomento à pesquisa.

A amostragem utilizada pelos autores pode refletir o perfil da área acadêmica da Química no país, mesmo considerando-se que ela ainda carece deste tipo de bolsas, pois há pressão de novos bons pesquisadores desejando entrar no sistema.

Não nos surpreende que a Química tenha sido escolhida a subárea para a realização deste estudo. Ao longo dos anos o seu comitê tem tentado encontrar caminhos mais justos e estabelecer padrões mais confiáveis de avaliação para estas bolsas e, também, para outras bolsas e projetos. Os resultados destas reuniões têm sido regularmente publicados no Boletim Eletrônico da Sociedade Brasileira de Química, para que a comunidade tome consciência não só da suas decisões mas, também, dos métodos que serão utilizados nas avaliações futuras.

Considerando que as bolsas de produtividade, de certa forma, refletem o grau de desenvolvimento da Química numa região, os números apresentados por Santos e colaboradores ${ }^{1}$ mostram como ela está desigualmente distribuída no país. Mesmo considerando que os atuais índices numéricos utilizados pelo Comitê Assessor de Química (índice H, somatório do JCR e índice de orientação nos últimos 5 anos) sejam questionados por muitos pesquisadores, qualquer outra fórmula puramente numérica chegará a resultado semelhante. É preocupante notar-se ausência de bolsistas, sem considerar o nível, em diversos estados e uma concentração destes na região sudeste $(63,74 \%)$.

Os autores foram bastante detalhistas e analisaram os bolsistas por gênero e encontraram que $32,8 \%$ das mulheres são bolsistas, com maior concentração na categoria 2 . Porém, há apenas $4,8 \%$ de participação feminina no nível $1 \mathrm{~A}$, valor bem inferior ao geral de bolsas do CNPq $(23,6 \%)$.

Em março foram comemorados os 100 anos do "Dia Internacional da Mulher". Este dia tem muitas conotações positivas, mas sua importância real é com a luta das mulheres por igualdade social. Apesar deste dia ter sido criado em 1910 associado a um fato muito triste e lamentável ocorrido em 1857, quando mulheres que eram exploradas por condições de trabalho próximas da escravidão foram assassinadas apenas por reivindicarem redução na carga de trabalho, é notório que atualmente as mulheres vêm alcançando funções de alto nível no mundo.

Muitos fatos históricos poderiam ser ressaltados indicando quando começou efetivamente a participação das mulheres. No Brasil, um marco histórico a ser destacado ocorreu em 24 de fevereiro de 1932, quando elas conquistaram direito de votar e serem eleitas para cargos no executivo e legislativo. A Química Nova, fundada em 1978, teve suas duas primeiras editoras já em abril de 1989 (vol. 12, № 2). Nesta oportunidade instituiu-se um corpo de três editores, a saber: Profas. Helena M. C. Ferraz e Vera L. Pardini que compuseram junto com o Prof. João V. Comasseto a Editoria da QN. Outro fato marcante para Química no Brasil foi a eleição em 2008 da primeira presidente da SBQ, Profa. Vanderlan Bolzani, mostrando que os membros da nossa Sociedade sabem reconhecer os cientistas pelos seus valores independente do sexo. É interessante ressaltar o resultado da premiação do Nobel de 2009, que bateu o recorde em termos de mulheres ganhadoras do prêmio; a Profa. Ada Yonath recebeu o Nobel de Química, sendo a quarta mulher a recebê-lo, após 45 anos desde a última concessão a uma mulher.

Apesar de não haver correlação com o trabalho do CNPq, é interessante observar também que apenas $4,4 \%$ das mulheres foram agraciadas em todas as edições do Prêmio Nobel, o que não representa a contribuição científica das mulheres na Química e na Ciência. ${ }^{2}$

Destes eventos mencionados acima podem ser tiradas muitas conclusões, mas o que é importante são as ações a serem tomadas. Se for desejo que a Química seja forte e desenvolvida no Brasil, é preciso ter uma Química ampla e forte em todos os estados, pois a desigualdade só aumenta prejuízos, diminui as oportunidades e competitividades. As mulheres têm conquistado igualdade de condições em muitas atividades em relação aos homens e isso também tem de acontecer em relação a sua participação na Química e na Ciência. Não existe nenhuma fórmula mágica instantânea para isso, porém é preciso muito equilíbrio na discussão com a comunidade e transparência total nos processos de avaliação.

Susana I. Córdoba de Torresi Vera L. Pardini Vitor F. Ferreira Editores de QN

\section{REFERÊNCIAS}

1. Santos, N. C. F.; Cândido, L. F. O.; Kuppens, C. L.; Quim. Nova 2010, 33,489

2. de Torresi, S. I. C.; Pardini, V. L.; Ferreira, V. F.; Quim. Nova 2009, 32, 1987. 